\section{Bøg og hvidløgstræ}

\author{
Af fhv. flyvenavigator Jorgen Jensen
}

\section{Olaus Magnus og magnetisk bøgetræ}

$\mathrm{R}$ omerkirkens titulære ærkebiskop af Uppsala, Olaus Magnus, udgav i 1555 Historia de gentibus septentrionalibus, ${ }^{1}$ De Nordiske Folks Historie. Blandt de mange ting han omtaler i bogen er magnetisme og kompasset. Her skal kun hans fortælling om magnetiseret bøgetræ behandles.

\section{2. bog, 26. kapitel fortæller}

Olaus Magnus, at magneter har en så stærk iboende kraft, at de forvandler bøgetræ til samme hårdhed som jern, og at magnetens kraft overføres til træet. I 12. bog, l. kapitel lyder det: "På øerne i polhavet findes der magnetiske bjerge, bryder man en sten og holder et stykke bøgetræ mod den, bliver træet så hårdt som stenen og får evne til at tiltrække genstande.” (Min oversættelse).

Olaus Magnus har, som alle historikere, trukket på mange kilder. Det er ikke lykkedes Olaus Magnus' omhyggelige kommentator John Granlund ${ }^{2}$ at finde kilden til oplysningerne om det magnetiske bøgetræ, i kommentaren til 12. bog, 1 . kapitel, skriver han: "bokträ, lat., ligna fagina. Varifrån O.M. fått denna uppgift är

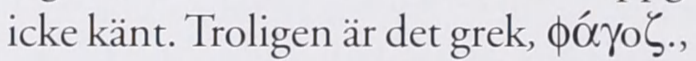
vilket spelar en roll i tidliga fabler om magnetstenen, som i latinska tekster skrivits fagus. Fagus betyder bøg." ${ }^{3}$ Det er ikke lykkedes mig at finde tidlige fabler om

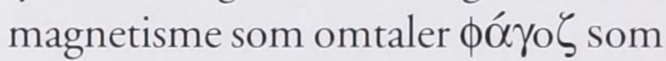

betyder "grovæder eller frådser." ${ }^{14} \mathrm{De}$ forfattere Olaus Magnus har trukket på er antagelig Plinius, Procopius og Ptolomæus, som alle tre er blandt hans kilder.

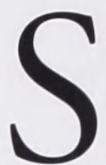
agnet om magnetiske klipper og øer er kendt fra Arabien til Nordeuropa, og fra den klassiske oldtid til det nittende århundrede. ${ }^{5}$ Nogle fortællinger er i årenes løb, gennem den mundtlige overførsel, blevet dramatiserede, som for eksempel historien om, at øernes magnetisme er så kraftig, at den kan trække naglerne ud af et skib, når det nærmer sig øen. Der er dog en kerne af sandhed i historierne, lokale magnetiske forstyrrelser findes mange steder. Et eksempel fra det syttende århundrede: Lucas Jacobsøn Debes fortæller i 1673 om de magnetiske forstyrrelser ved Sumbø Munk, lidt syd for Suderø på Færøerne, at magnetismen ved Munken og de omliggende skær er så kraftig, at hvis man lægger et kompas på en sten vil nålen begynde at løbe rundt og derefter er kompasset ubrugeligt. Videre fortæller Debes, at en skipper nogle år tidligere har fortalt folk på Suderø, at han var kommet så nær Sumbø Munk at hans kompasser var blevet ubrugelige, og at han havde måttet afbryde sin rejse hvis ikke bådsmanden havde haft en Segelsten (et af de talrige navne for magnetjern) hvormed han strøg kompasnålene indtil de viste rigtigt igen. ${ }^{6}$ I 1891 beskrives Munken således: " $31 \frac{1}{2}$ Kvartmil [ 1 kvartmil = 1 sømil $=1852 \mathrm{~m}]$. S. for Suderø ligger Klippen Munken, der tidligere ragede omtrent 100 Fod [ 1 Fod $=0.3185 \mathrm{~m}$ ] op over Vandet, men nu delvis nedfalden, saa dens Høide næppe er mere end 30 Fod. Nogle Kabellængder [Kabellængde $=1 / 10$ sømil $=$ $185.2 \mathrm{~m}]$ ØNØ for denne ligger nogle Fleser [småøer, holme] som imidlertid er ganske lave". ${ }^{7}$ Om magnetiske forstyrrelser i 


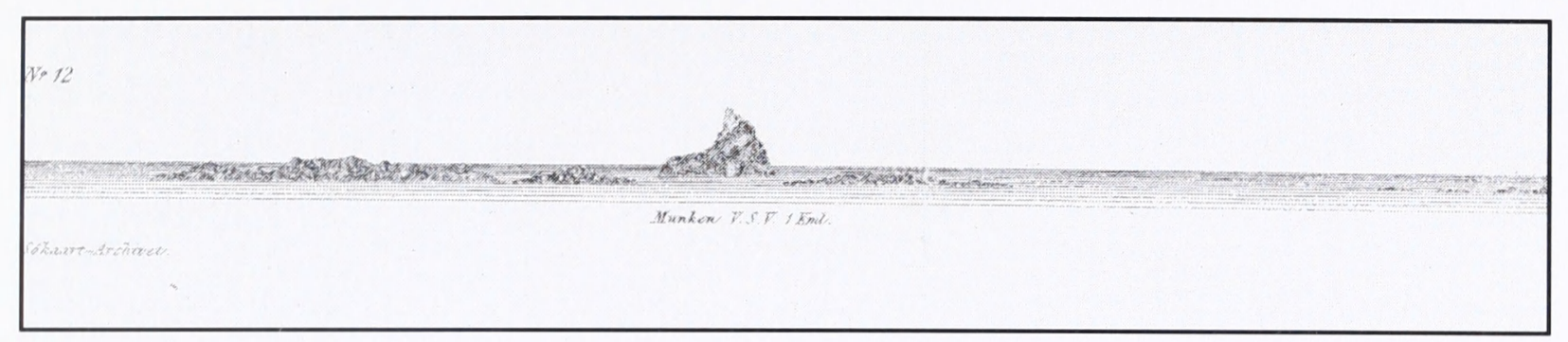

Illustration af Sumbo Munk. (Forøske Lods 1891, Tavle II).

området hedder det: ... ”Tæt ved Kysten paavirkes Kompasset meget af Øernes jernholdige Basaltmasser og er derfor ikke paalideligt ..." ${ }^{\prime 8}$

\section{William Gilbert fra Colchester og De magnete}

45 år efter Olaus Magnus' Historia udgav William Gilbert fra Colchester De magnete? Gilbert beskriver de forskellige former for ovetro vedrørende magnetisme, og viser ved forsøg, at de er uden bund i virkeligheden. Gilbert refererer ikke direkte til magnetisk bøgetræ; men i 13. kapitel skriver han, at det er umuligt at magnetisere træ. Endnu en repræsentant for planteriget optræder i overtroen: hvidløget. Gilbert skriver, at det er almindelig overtro at hvidløg kan afmagnetisere, og at det er forbudt for rorgængere at spise hvidløg. Gilbert var lige så praktisk som lærd. Hans forsøg var enkle, først spiste han hvidløg, derefter åndede og bøvsede (breathing and belching) han på kompasnålen. Det havde ingen som helst virkning på nålens visning. Han smurte kompasnåle ind i hvidløgssaft - heller ikke dette havde nogen effekt på nålenes retningsvisning. Gilbert spurgte nogle sømænd om deres mening om sagen, de svarede at de hellere ville dø end at undlade at spise $\operatorname{lgg}$ og hvidløg. Engelske søfolk synes i 1600 at have vidst, hvordan skørbug forebygges, 200 år før Admiralitetet anerkendte grøntsager og frugt som det eneste effektive middel mod skørbug. ${ }^{10}$

\section{P.W. Lund og det magnetiske hvidløgs-} træ

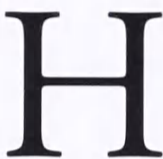

vidløg og træ kombineret i hvidløgstræet forekommer i en rapport fra Brasilien. ${ }^{11}$ P.W. Lund var på rejse i Brasiliens indre højslette. I urskoven nordvest for floden Piracicaba fandt han "det mærkelige træe som brasilianerne kalder pão d'alho"12 (hvidløgstræet), Cerdana alliodura. Lund så ikke træet i blomst, men efter at have undersøgt frugterne fastslog han, at det ikke var en Cerdana. Lunds beskrivelse siger, at træet udbreder så stærk en hvidløgslugt, at det kan mærkes på lang afstand. Træet indsuger så meget vand, at det kan udtørre en egn. Det har en anden egenskab som må være i fysiologisk forbindelse med absorptionskraften, idet dets løv frigiver så meget vand, at det i flere timer er som at være ude $\mathrm{i}$ regnvejr, hvis man stiller sig under det. Lund fortsætter: "Ifølge en i Brasilien almindelig udbredt Mening skal nemlig Nærheden af dette Træe frembringe Misvisning og Bevægelser i samme [magnetnålen] og denne Ting har været mig forsikret af Personer, om hvis Paalidelighed jeg ei kan nære nogen Tvivl, blandt andet af Hr. Ingenieur-Major v. Blom, der under vort Ophold i Ypanema var beskjæftiget med at optage Planen til 


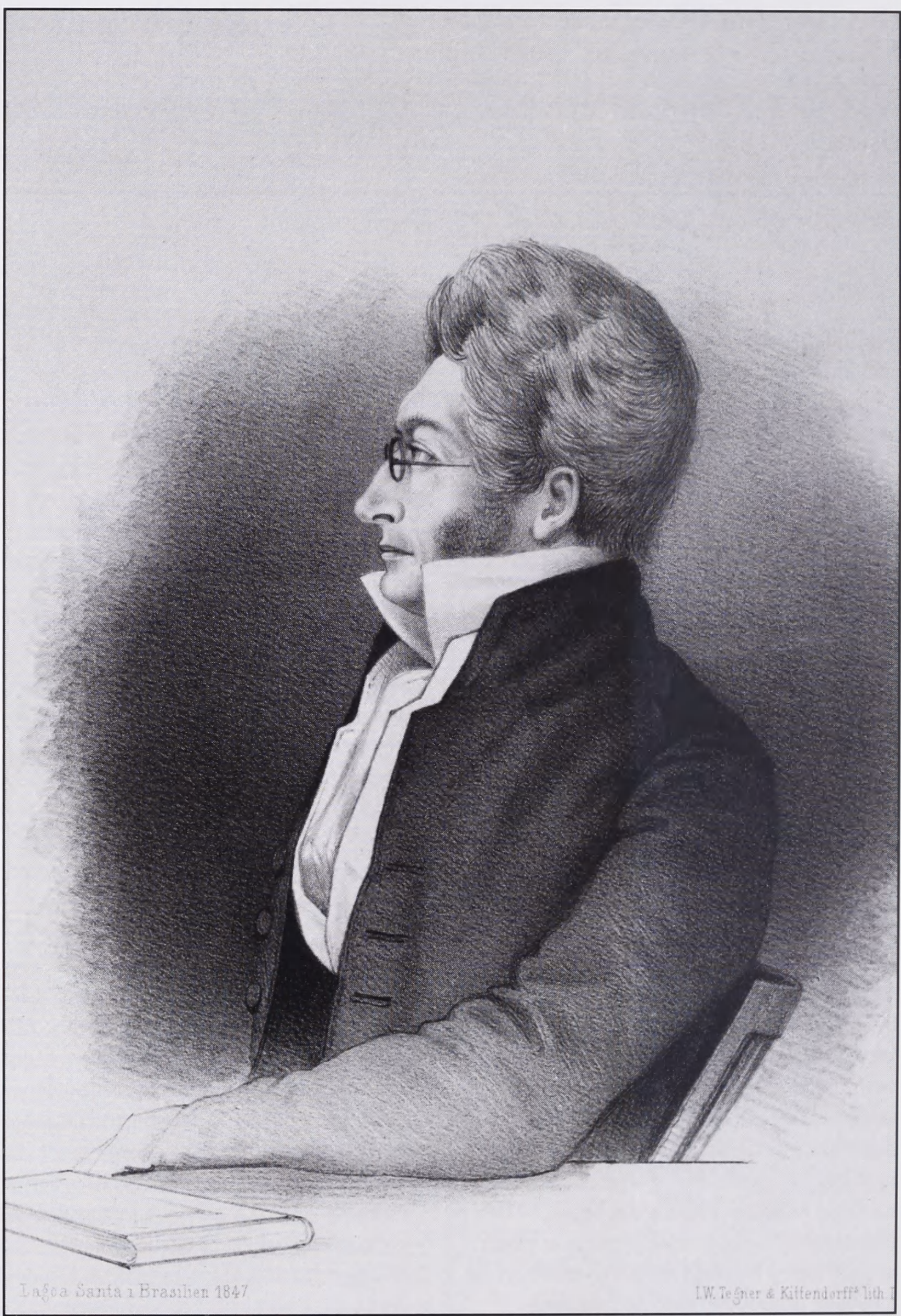

Peter Wilhelm Lund 1801-1880. (Foto: Det Kongelige Bibliotek, Billedsamlingen). 
dette berömte Jernværk. Jeg har sögt at overbevise mig om Rigtigheden af dette Factum ved egne Forsög, og skjöndt det ei var mig muligt at anstille dem med den Nöiagtighed, jeg havde önsket, vare Resultaterne dog saadanne, at de ei lode nogen Tvivl tilbage". For yderligere at overbevise sig om dette resultat tog Lund sin tilflugt "til den Substants hvormed dette Træe i Lugt og Smag har saa frappant en Lighed, Hvidlög”. Lund skar et hvidøg mit over og holdt snitfladen hen til magnetnål. Hver gang han gjorde det, blev nålen ftastødt. Lund mente, at det var den mekaniske virkning af den udstrømmende hvidløgslugt der var årsagen. Han besluttede derfor til at prøve med noget andet stærkt lugtende og valgte kamfer. Resultatet var det samme, når han førte kamferen hen til magnetnålen blev den frastødt. Lund slutter: "Maaskee ere disse Facta længe bekjendte i Videnskaben, for mig tilstaar jeg vare de ubekjendte, og det glædede mig ved dem at faae en tilfredsstillende Forklaring af det mærkelige Phænomen, som Hvidlögstræet frembyder."
Jeg har, med assistance fra Handels- og Søfartsmuseet, gentaget Lunds forsøg med hvidløg. Forsøget blev gjort med to fri kompasnåle, den ene kompenseret for dip, den anden ukompenseret. Et frisk overskåret hvidløg blev holdt hen til nålen. Resultatet blev det samme som ved William Gilberts 399 år ældre forsøg, kompasnålene blev ikke påvirket af hvidløget. Mikael Sterll, Botanisk Museum, har gjort lignende forsøg med hvidløg, kamfer og et stykke træ fra "Gallesia garazema“, som hvidløgstræets nuværende navn er. ${ }^{13}$ Heller ikke han observerede nogen indvirkning på nålens visning.

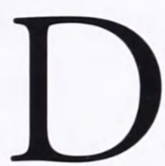
en sandsynligste forklaring på Lunds observationer fra Brasiliens højslette jeg kan komme til er, at pão d'alho foretrækker en jordbund med højt jernindhold. En rimelig forklaring på Lunds forsøg med hvidløg og kamfer er sværere at give, for det er næsten utænkeligt at en videnskabsmand af P.W. Lunds karat skulle have rakt hvidløg og kamfer frem mod magnetnålen på spidsen af en jernkniv. 
Noter:

1. Olaus Magnus 1555, Historia de gentibus septentrionalibus, Rom 1555. Her er brugt den svenske oversættelse: Historia om de Nordiska Folken, Vol. 1 - 5, Uppsala 1909 1951.

2. Granlund, John, Olaus Magnus Historia om de Nordiska Folken, Femte Delen, Kommentar, Uppsala 1951.

3. Se f.eks.: Lewis, C.T. \& Short, C., A Latin Dictionary, Oxford 1969, p. 720.

4. Arnesen, Paul, Grask-Dansk Ordbog, København 1830, p. 743 eller Lidell, Henry George \& Scott, Robert, A GreekEnglish Lexicon, Oxford 1966, p. 1911.

5. Et eksempel fra den arabiske verden er: 1001 $N$ a.t Fra det nordiske område se f.eks. Feilberg, H.F., Bidrag til en Ordbog over jyske Almuemaal, I - IV, København 1886 1914, Vol. II, p. 530.

6. Debes, Lucas Jacobssøn, Faeroae \& Faeroa Reserata, København 1673. Faksimileudgaven Torshavn 1963, pp. 12 -13 er brugt her.

7. Det Kongelige Søkaart-Archiv, Den Farøiske Lods 1891, København 1891, p. 9.

8. Søkortarkivet, Den Ferøske Lods 1899 , København 1899, p. 3.

9. Gilbert, William, De Magnete, London 1600. Her er brugt faksimileudgaven New York I 958 af den engelske oversættelse $O n$ the Magnet, London 1900, pp. 33 - 34. Se også Thompson, Silvanus P., Notes on the De Magnete of Dr. William Gilbert, London 1901, p. 29. (Omhandler bl. a.

Dioscorides, Galens og andres tro på magnetstens medicinske virkning).

10. Se Lauring, Kåre, Skørbug og dens helbredelse - et spørgsmål om teori eller praksis, i: Handels og Sofarts- museets Arbog 1999, Helsingør 1999, pp. 63 - 91.

11. Lund, P.W., Sarskilt Aftryk af Det Kongelige Danske Videnskabernes Selskabs Skrifter, forelæst d. 10. Juli 1835, København 1835., pp. 22 - 24 n. Af Videnskabernes Selskabs protokol fra mødet d. 10. Juli 1835, fremgår det, at H.C. Ørsted ikke var til stede, det havde været interessant at have hans reaktion på oplysningen om magnetisk Træ.

12. Pão, med akcent som Lund skriver, betyder brød eller korn; mens pao uden akcent betyder kæp, stok eller tømmer. Se f.eks:Michaelis, H., Nova Dictionario da Portugucza et allemana, Leipzig1914, p. 538. Gregersen, A.H., Dictionario PortuguesDinamarques, København 1967 kender kun ordet med akcent og kun betydningen brød eller korn.

13. Jette Dahl Møller, Botanisk Have og Mikael Sterll, Botanisk Museum takkes for oplysninger om træet og dets forskellige navne. Sidstnævnte også for oplysningerne om forsøget med magnetnålen. 